\title{
PENGARUH WORKING CAPITAL TURNOVER, DEBT TO TOTAL ASSET DAN RECEIVABLE TURNOVER TERHADAP PERTUMBUHAN LABA
}

\author{
Studi Empiris Pada Perusahaan Sektor Makanan Dan Minuman \\ Yang Terdaftar Di Bursa Efek Indonesia
}

\author{
${ }^{1}$ Surya Ridhoansyah, ${ }^{2}$ Zenni Riana, ${ }^{3}$ Eli Agustami \\ ${ }_{1,2,3}$ Universitas Islam Sumatera Utara \\ ${ }^{1}$ suryaridho67@gmail.com, ${ }^{3}$ zenni.riana@ fe.uisu.ac.id, ${ }^{3}$ eli.agustami@fe.uisu.ac.id
}

\begin{abstract}
This study aims to determine the effect of working capital turnover, debt to total assets and receivable turnover with profit growth. The type of data used is quantitative data. Determination of the sample was carried out using purposive sampling technique, and there were 12 companies in the food and beverage sector that were sampled in this study. The data analysis technique used is multiple linear regression analysis. The data source used is secondary data obtained from the Indonesia Stock Exchange, by taking financial statement data, in 2017 to 2020. The results of this study indicate that partially debt to total assets has a positive and significant effect on profit growth, and receivable turnover has an effect negative and significant to profit growth. Meanwhile, working capital turnover has no and no significant effect on profit growth.
\end{abstract}

Keywords : Working Capital Turnover, Debt To Total Asset, Receivable Turnover, Profit Growth

ABSTRAK : Penelitian ini bertujuan yaitu untuk dapat mengetahui pengaruh antara working capital turnover, debt to total asset dan receivable turnover dengan pertumbuhan laba. Jenis data yang digunakan yaitu data kuantitatif. Penentuan sampel dilakukan dengan menggunakan teknik purpossive sampling, dan terdapat 12 perusahaan pada sektor makanan dan minuman yang menjadi sampel pada penelitian ini. Teknik analisis data yang digunakan yaitu analisis regresi linier berganda. Sumber data yang digunakan yaitu data sekunder yang diperoleh dari Bursa Efek Indonesia, dengan mengambil data laporan keuangan, pada tahun 2017 sampai dengan 2020. Hasil penelitian ini menunjukkan bahwa secara parsial debt to total asset berpengaruh positif dan signifikan terhadap pertumbuhan laba, dan receivable turnover berpengaruh negatif dan signifikan terhadap pertumbuhan laba. Sedangkan working capital turnover tidak berpengaruh dan tidak signifikan terhadap pertumbuhan laba.

Kata Kunci : Working Capital Turnover, Debt To Total Asset, Receivable Turnover, Pertumbuhan Laba

\section{Pendahuluan}

\subsection{Latar Belakang Masalah}

Salah satu kesuksesan pada suatu organisasi, dapat dilihat dari hasil perolehan laba setiap tahunnya. Laba yang telah diperoleh kemudian dianalisis, sehingga dapat dikenal dengan pertumbuhan laba dari tahun ke tahun. Pertumbuhan laba pada perusahaan sangat perlu untuk dicermati kesesuaiannya dengan target yang telah ditetapkan oleh perusahaan. pertumbuhan laba dapat dihitung dari hasil perolehan laba bersih tahun ini dikurangi dengan laba bersih tahun sebelumnya, kemudian dibagikan ataupun dibandingkan dengan perolehan laba bersih tahun sebelumnya (Lina, 2017). Untuk memprediksi tingkat pertumbuhan laba pada suatu perusahaan, diperlukan analisis terhadap laporan keuangan yang diduga dapat mempengaruhi besar atau kecilnya laba yang diperoleh, yaitu rasio keuangan yang terdiri dari rasio aktivitas dan rasio solvabilitas (Purwitasari, 2019).

Working capital turnover merupakan pengukuran pada rasio aktivitas yang digunakan untuk menilai keefektivan modal kerja perusahaan selama periode tertentu. Artinya seberapa banyak modal kerja dapat berputar selama suatu periode. Perputaran modal kerja 
yang semakin cepat menandakan penggunaan modal kerja yang efisien dan tentunya investasi yang telah tertanam dalam modal kerja semakin kecil. Perputaran modal kerja juga dipengaruhi oleh besar atau kecilnya jumlah penjualan, aset lancar dan hutang lancar yang digunakan untuk memenuhi kebutuhan operasional pada suatu perusahaan. Semakin cepat suatu periode pengembalian menjadi kas, maka akan semakin pula modal kerja dapat berputar pada suatu perusahaan, sehingga besar suatu peluang bagi perusahaan untuk mendapatkan laba atas dana yang telah ditanam, dan pertumbuhan laba pada perusahaan juga dapat dimaksimalkan.

Debt to asset ratio merupakan salah satu rasio solvabilitas yang dapat digunakan untuk mengukur besar atau kecilnya jumlah aktiva perusahaan yang dibiayai dengan jumlah hutang secara keseluruhan yang dimiliki oleh perusahaan. Semakin tinggi rasio ini, maka semakin besar jumlah modal pinjaman atau hutang yang digunakan untuk melakukan investasi pada aktiva, dengan tujuan untuk menghasilkan keuntungan serta meningkatkan pertumbuhan laba bagi perusahaan. Namun sebaliknya, semakin kecil rasio ini, maka semakin kecil pula jumlah hutang yang digunakan untuk berinvestasi pada aktiva, sehingga dapat menyebabkan profit atau keuntungan semakin berkurang dan pertumbuhan laba pada perusahaan juga tidak dapat dimaksimalkan.

Receivable turnover atau perputaran piutang juga menjadi salah satu faktor yang dapat mempengaruhi pertumbuhan laba pada suatu perusahaan, karena menunjukkan penagihan piutang selama satu periode. Jika perusahaan mampu melakukan pengelolaan piutangnya dengan baik, serta dapat membayar semua kewajibannya dengan tepat waktu, maka akan memungkinkan bahwa perusahaan tersebut dapat beroperasi dengan lebih efektif, karena tidak memperoleh barang dan jasa yang diperlukan, sehingga secara tidak langsung akan berdampak pada tingkat pertumbuhan laba setiap tahunnya pada suatu perusahaan, dan begitu pula sebaliknya.

\section{Landasan Teori}

\subsection{Working Capital Turnover}

Working capital turnover atau perputaran modal kerja merupakan salah satu rasio untuk mengukur atau menilai keefektifan modal kerja perusahaan selama periode tertentu. Artinya seberapa banyak modal kerja berputar selama suatu periode. Perputaran modal kerja juga merupakan salah satu rasio aktivitas, serta perbandingan antara penjualan dengan aktiva lancar, kemudian dikurangi dengan utang lancar. Perhitungan pada working capital turnover dapat ditentukan dengan rumus sebagai berikut :

$$
\begin{gathered}
\text { Perputaran Modal Kerja } \\
\frac{\text { Penjualan Bersih }}{\text { Modal Kerja Rata-Rata }}
\end{gathered}=
$$

\subsection{Debt To Total Asset}

Debt to total asset atau struktur aktiva adalah rasio utang yang digunakan untuk mengukur perbandingan antara total hutang dengan total aktiva. Dengan kata lain, seberapa besar aktiva perusahaan dibiayai oleh hutang atau seberapa besar hutang perusahaan berpengaruh terhadap pengelolaan aktiva. Kreditur cenderung lebih menyukai debt ratio yang rendah, sebab tingkat keamanan menjadi semakin baik. Perhitungan pada debt to total asset dapat ditentukan dengan rumus sebagai berikut :

$$
\text { Debt To Asset Ratio }=\frac{\text { Total Debt }}{\text { Total Asset }}
$$

\subsection{Receivable Turnover}

Receivable turnover atau perputaran piutang adalah rasio yang dapat digunakan untuk mengukur berapa lama penagihan piutang selama satu periode atau berapa kali dana yang ditanam dalam piutang ini berputar dalam satu periode. Cara mencari rasio ini adalah dengan membandingkan antara penjualan secara kredit dengan rata - rata piutang. Perhitungan pada receivable turnover dapat ditentukan dengan rumus sebagai berikut :

$$
\text { Receivable Turnover }=\frac{\text { Penjualan Kredit }}{\text { Rata }- \text { Rata Piutang }}
$$

\subsection{Pertumbuhan Laba}

Pertumbuhan laba adalah suatu perubahan persentase kenaikan dan penurunan laba yang diperoleh perusahaan. pertumbuhan juga berkaitan dengan terjadinya stabilitas peningkatan laba. Pengukuran yang digunakan untuk mengukur pertumbuhan laba pada suatu perusahaan yaitu rasio pertumbuhan. Rasio ini menggambarkan persentase peningkatan dan penurunan laba setiap tahunnya, sekaligus menunjukkan kemampuan perusahaan dalam meningkatkan laba bersih tahun lalu. 
Perhitungan pada pertumbuhan laba dapat ditentukan dengan rumus sebagai berikut :

Pertumbuhan Laba $=$

Laba Tahun Sekarang - Laba Bersih Tahun Lalu Laba Bersih Tahun Lalu

\section{Metode Penelitian}

\subsection{Populasi Dan Sampel}

Populasi merupakan wilayah generalisasi yang terdiri atas sekelompok orang, kejadian atau segala sesuatu yang mempunyai karakteristik tertentu. Populasi pada penelitian ini yaitu sebanyak 26 perusahaan pada sektor makanan dan minuman yang terdaftar ataupun tercatat di Bursa Efek Indonesia.

Sampel merupakan bagian dari jumlah maupun karakteristik yang dimiliki populasi, dan dipilih secara hati - hati dari populasi tersebut. Untuk melakukan penarikan sampel, maka teknik yang dapat digunakan adalah purpossive sampling, yang merupakan teknik penentuan sampel dengan berbagai pertimbangan tertentu, serta beberapa kriteria yang telah ditentukan oleh peneliti. Dalam hal ini, maka dapat diperoleh sampel yaitu sebanyak 12 perusahaan pada sektor makanan dan minuman yang terdaftar di Bursa Efek Indonesia.

\subsection{Sumber Data}

Sumber data yang digunakan pada penelitian ini yaitu data sekunder, yang merupakan suatu sumber data penelitian yang diperoleh secara tidak langsung melalui media perantara seperti informasi yang diakses melalui internet, serta jurnal, artikel dan buku bacaan yang bertujuan untuk memberikan informasi tambahan yang berkaitan dengan masalah penelitian.

\subsection{Teknik Pengumpulan Data}

Teknik pengumpulan data yang digunakan dalam memperoleh informasi serta berkaitan dengan penelitian ini, yaitu sebagai berikut :

a. Studi Dokumentasi, merupakan suatu teknik dengan mengumpulkan data berupa laporan keuangan yang diperoleh dari Bursa Efek Indonesia melalui situs resmi www.idx.co.id. Dalam hal ini, data yang diperoleh merupakan suatu data yang terkait dengan penelitian.

b. Studi Pustaka, merupakan suatu kegiatan yang bertujuan untuk menghimpun informasi tambahan yang dapat diperoleh dari buku, jurnal, karya ilmiah, artikel, ensiklopedia dan informasi lainnya yang berkaitan dengan penelitian.

\subsection{Teknik Analisis Data}

Analisis yang digunakan pada penelitian adalah regresi linier berganda, merupakan suatu analisis yang bertujuan untuk memberikan prediksi perubahan nilai variabel terikat, akibat atau pengaruh dari nilai variabel independen atau variabel bebas (Juliandi, 2013).

\section{Hasil Penelitian}

\subsection{Analisis Statistik Deskriptif}

Tabel 1. Statistik Deskriptif

Descriptive Statistics

\begin{tabular}{|c|c|c|c|c|c|}
\hline & $\mathrm{N}$ & Minimum & Maximum & Mean & $\begin{array}{c}\text { Std. } \\
\text { Deviation }\end{array}$ \\
\hline $\begin{array}{l}\text { Working Capital } \\
\text { Turnover }\end{array}$ & 48 & $-785,54$ & 33,21 & 10,096 & 114,67550 \\
\hline Debt To Total Asset & 48 &, 15 & ,91 & ,4085 &, 17418 \\
\hline Receivable Turnover & 48 & 2,53 & 18,14 & 7,7388 & 3,63626 \\
\hline Pertumbuhan Laba & 48 &,- 94 & 8,52 & ,4223 & 1,47336 \\
\hline Valid N (listwise) & 48 & & & & \\
\hline
\end{tabular}

Berdasarkan hasil analisis pada data output di atas, maka dapat diketahui bahwa jumlah nilai $\mathrm{N}$ atau jumlah data pada setiap variabel yaitu sebanyak 48 data. Hasil tersebut dapat diperoleh dari jumlah sampel yang diteliti yaitu sebanyak 12 perusahaan, dengan jangka waktu penelitian selama 4 tahun. Dari hasil pada data output di atas, dapat diketahui bahwa :

1. Working Capital Turnover $\left(\mathrm{X}_{1}\right)$ memiliki nilai minimum dengan jumlah $-785,54$, nilai maksimum dengan jumlah 33,21 , nilai rata - 
rata (mean) dengan jumlah $-10,0969$, dan standar deviasi sebesar 114,67550.

2. Debt To Total Asset $\left(\mathrm{X}_{2}\right)$ memiliki nilai minimum dengan jumlah 0,15 , nilai maksimum dengan jumlah 0,91 , nilai rata rata (mean) dengan jumlah 0,4085 , dan standar deviasi dengan jumlah 0,17418 .

3. Receivable Turnover $\left(\mathrm{X}_{3}\right)$ memiliki nilai minimum dengan jumlah 2,53 , nilai maksimum dengan jumlah 18,14 , nilai rata rata (mean) dengan jumlah 7,7388 , dan standar deviasi dengan jumlah 3,63626.

4. Pertumbuhan Laba (Y) memiliki nilai minimum dengan jumlah $-0,94$, nilai maksimum dengan jumlah 8,52 , nilai rata rata (mean) dengan jumlah 0,4223, dan standar deviasi dengan jumlah 1,47336.

\subsection{Uji Parsial (Uji t)}

Tabel 2. Uji Signifikansi Parsial

Coefficients $^{\mathrm{a}}$

\begin{tabular}{|c|c|c|c|c|c|}
\hline \multirow[b]{2}{*}{ Model } & \multicolumn{2}{|c|}{$\begin{array}{l}\text { Unstandardized } \\
\text { Coefficients }\end{array}$} & \multirow{2}{*}{$\begin{array}{c}\begin{array}{c}\text { Standardize } \\
\mathrm{d} \\
\text { Coefficients }\end{array} \\
\text { Beta }\end{array}$} & \multirow[b]{2}{*}{$\mathrm{t}$} & \multirow[b]{2}{*}{ Sig. } \\
\hline & B & $\begin{array}{l}\text { Std. } \\
\text { Error }\end{array}$ & & & \\
\hline $1 \quad$ (Constant) & ,543 & ,089 & & 6,103 &, 00 \\
\hline $\begin{array}{l}\text { Working Capital } \\
\text { Turnover }\end{array}$ & $\begin{array}{r}7,305 \mathrm{E} \\
-5\end{array}$ &, 000 & ,044 & ,339 & ,7 \\
\hline Debt To Total Asset & ,309 & , 130 & ,297 & 2,370 &, 02 \\
\hline Receivable Turnover &,- 024 & ,007 &,- 448 & $-3,461$ & 00 \\
\hline
\end{tabular}

a. Dependent Variable: Pertumbuhan Laba

Berdasarkan hasil analisis pada data output di atas, maka peneliti akan menarik suatu kesimpulan dengan cara membandingkan nilai signifikansi (Sig.) dengan tingkat signifikansi yaitu sebesar $0,05 \quad(\alpha=5 \%)$, serta membandingkan nilai $t_{\text {hitung }}$ dengan $t_{\text {tabel }}$ yaitu sebesar 2,015. Pada berbagai perbandingan yang telah dilakukan, maka dapat diambil kesimpulan sebagai berikut :

a. Working Capital Turnover memiliki nilai signifikansi sebesar 0,736>0,05 dan nilai $\mathrm{t}_{\text {hitung }}$ sebesar $0,339<2,015$. Maka $\mathrm{Ha}$ ditolak dan Ho diterima, dan dapat disimpulkan bahwa Working Capital Turnover tidak berpengaruh dan tidak signifikan terhadap Pertumbuhan Laba. b. Debt To Total Asset memiliki nilai signifikansi sebesar $0,022<0,05$ dan nilai $\mathrm{t}_{\text {hitung }}$ sebesar 2,370 < 2,015. Maka $\mathrm{Ha}$ diterima dan Ho ditolak, dan dapat disimpulkan bahwa Debt To Total Asset berpengaruh positif dan signifikan terhadap Pertumbuhan Laba.

c. Receivable Turnover memiliki nilai signifikansi sebesar $0,001<0,05$ dan nilai $\mathrm{t}_{\text {hitung }}$ sebesar $-3,461>-2,015$. Maka Ha diterima dan Ho ditolak, dan dapat disimpulkan bahwa Receivable Turnover berpengaruh negatif dan signifikan terhadap Pertumbuhan Laba.

\subsection{Uji Simultan (Uji F)}

Tabel 3. Uji Signifikansi Simultan

\begin{tabular}{|c|c|c|c|c|c|}
\hline \multicolumn{6}{|c|}{ ANOVA $^{\mathrm{a}}$} \\
\hline Model & $\begin{array}{l}\text { Sum of } \\
\text { Squares }\end{array}$ & df & $\begin{array}{l}\text { Mean } \\
\text { Square }\end{array}$ & $\mathrm{F}$ & Sig. \\
\hline $1 \quad$ Regression & ,549 & 3 & , 183 & 6,917 &, $001^{\mathrm{b}}$ \\
\hline Residual & 1,164 & 44 & ,026 & & \\
\hline Total & 1,713 & 47 & & & \\
\hline
\end{tabular}

a. Dependent Variable: Pertumbuhan Laba

b. Predictors: (Constant), Receivable Turnover, Debt To Total Asset, Working Capital

Turnover 
Berdasarkan hasil analisis pada data output di atas, maka peneliti akan menarik suatu kesimpulan dengan cara melakukan perbandingan nilai signifikansi (Sig.) dengan tingkat signifikansi yaitu sebesar $0,05(\alpha=5 \%)$, serta membandingkan nilai $\mathrm{f}_{\text {hitung }}$ dengan $\mathrm{f}_{\text {tabel }}$ yaitu sebesar 2,81 .

Pada berbagai perbandingan yang telah ditentukan, maka dapat diketahui bahwa variabel independen secara keseluruhan memiliki nilai signifikansi sebesar $0,001<0,05$ dan nilai $\mathrm{f}_{\text {hitung }}$ sebesar 6,917>2,81. Maka Ha diterima dan Ho ditolak, sehingga dapat disimpulkan bahwa variabel independen yang terdiri dari Working Capital Turnover, Debt To Total Asset dan Receivable Turnover berpengaruh positif dan signifikan terhadap Pertumbuhan Laba.

\subsection{Koefisien Determinasi $\left(\mathbf{R}^{2}\right)$}

Tabel 4. Pengujian Determinasi

Model Summary ${ }^{\mathrm{b}}$

\begin{tabular}{|l|c|r|r|r|}
\hline Model & R & R Square & $\begin{array}{c}\text { Adjusted R } \\
\text { Square }\end{array}$ & $\begin{array}{c}\text { Std. Error of } \\
\text { the Estimate }\end{array}$ \\
\hline 1 &, $566^{\mathrm{a}}$ &, 320 &, 274 &, 16267 \\
\hline
\end{tabular}

a. Predictors: (Constant), Receivable Turnover, Debt To Total Asset, Working

Capital Turnover

b. Dependent Variable: Pertumbuhan Laba

Sumber : Data SPSS, 2021

Berdasarkan hasil pengujian pada tabel di atas, maka dapat diketahui bahwa nilai koefisien determinasi atau $R$ Square sebesar 0,320 , yang kemudian dihitung dalam satuan persen $(\%)$, yaitu sebagai berikut

$$
\text { KD }: 0,320 \times 100 \%=32 \%
$$

Dari hasil perhitungan tersebut, maka besarnya nilai koefisien determinasi ( $R$ Square) sama dengan $32 \%$. Maka dapat disimpulkan bahwa kemampuan variabel independen secara keseluruhan, dalam menerangkan variasi pada variabel dependen yaitu sebesar $32 \%$, sedangkan selebihnya yaitu $68 \%$ dipengaruhi oleh variabel yang lain diluar penelitian.

\section{Evaluasi}

\subsection{Pengaruh Working Capital Turnover Terhadap Pertumbuhan Laba}

Hasil penelitian ini menunjukkan bahwa working capital turnover tidak berpengaruh dan tidak signifikan terhadap pertumbuhan laba. Hal ini dapat mengindikasikan bahwa semakin tinggi perputaran modal kerja, maka keefektivan modal kerja pada perusahaan juga akan semakin baik. Namun hal ini tidak berdampak secara langsung terhadap pertumbuhan laba pada perusahaan.

Perputaran modal kerja atau working capital turnover merupakan salah satu rasio untuk mengukur atau menilai keefektifan modal kerja perusahaan selama periode tertentu. Artinya seberapa banyak modal kerja berputar selama suatu periode atau dalam suatu periode.
Modal kerja merupakan suatu dana yang tersedia, dengan tujuan digunakan pembelian bahan mentah, membayar upah buruh dan gaji pegawai (Kasmir, 2017).

\subsection{Pengaruh Debt To Total Asset Terhadap Pertumbuhan Laba}

Hasil penelitian ini menunjukkan bahwa debt to total asset berpengaruh positif dan signifikan terhadap pertumbuhan laba. Hal ini dapat mengindikasikan bahwa semakin tinggi struktur aktiva yang dimiliki oleh perusahaan, maka akan semakin besar jumlah hutang yang akan digunakan untuk membiayai aktiva, serta aktivitas operasionalnya, dengan tujuan agar pertumbuhan laba pada perusahaan, dapat meningkat setiap tahunnya.

Struktur aktiva atau debt to total asset adalah rasio utang yang digunakan untuk mengukur perbandingan antara total hutang dengan total aktiva. Dengan kata lain, seberapa besar aktiva perusahaan dibiayai oleh utang atau seberapa besar utang yang dimiliki oleh perusahaan, berpengaruh terhadap pengelolaan aktiva. Kreditur cenderung lebih menyukai debt ratio yang rendah, sebab tingkat keamanan menjadi semakin baik (Kasmir, 2017).

\subsection{Pengaruh Receivable Turnover Terhadap Pertumbuhan Laba \\ Hasil penelitian ini menunjukkan bahwa receivable turnover berpengaruh negatif dan signifikan terhadap pertumbuhan laba. Hal ini dapat mengindikasikan bahwa semakin tinggi}


tingkat perputaran piutang pada suatu perusahaan, maka pertumbuhan laba juga akan semakin menurun. Hal ini disebabkan oleh ketidakmampuan pada perusahaan dalam membayar semua kewajibannya dengan tepat waktu, sehingga perusahaan tidak dapat beroperasi secara efektif untuk menghasilkan laba.

Perputaran piutang atau receivable turnover merupakan rasio yang digunakan untuk mengukur berapa lama penagihan piutang selama satu periode atau berapa kali dana yang ditanam dalam piutang ini berputar dalam satu periode. Prosedur penagihan piutang yang tepat waktu menjadi suatu hal yang sangat baik untuk ditetapkan, sehingga dapat mengurangi resiko terganggunya likuiditas pada suatu perusahaan, akibat adanya piutang yang tidak tertagih (Kasmir, 2017).

\subsection{Pengaruh Working Capital Turnover, Debt To Equity Ratio Dan Receivable Turnover Terhadap Pertumbuhan Laba}

Hasil penelitian ini menunjukkan bahwa working capital turnover, debt to total asset dan receivable turnover berpengaruh positif dan signifikan terhadap pertumbuhan laba. Hal ini dapat mengindikasikan bahwa modal kerja adalah suatu dana yang tersedia untuk membiayai aktivitas operasional perusahaan, dengan harapan bahwa dana yang dikeluarkan tersebut, dapat kembali dalam jangka pendek, melalui hasil penjualan. Semakin tinggi perputaran modal kerja, maka keefektivan modal kerja pada perusahaan juga semakin baik, sehingga dana yang telah digunakan tersebut dapat kembali masuk, dan perolehan laba juga akan semakin meningkat setiap tahunnya. Hasil perolehan laba tersebut dapat dimanfaatkan oleh perusahaan untuk membayar semua kewajibannya dengan tepat waktu, dan perusahaan juga dapat memperoleh dana dari pihak luar untuk membiayai aktiva perusahaan, dengan tujuan agar pertumbuhan laba pada suatu perusahaan dapat meningkat setiap tahunnya.

\section{Kesimpulan}

Penelitian ini bertujuan untuk mengetahui pengaruh atau keterkaitan working capital turnover, debt to total asset dan juga receivable turnover terhadap pertumbuhan laba secara parsial maupun simultan, pada perusahaan sektor makanan dan minuman yang terdaftar di Bursa Efek Indonesia (BEI) periode 2017 sampai dengan 2020. Berdasarkan hasil penelitian yang telah dilakukan, maka dapat diambil suatu kesimpulan, yaitu sebagai berikut

a. Working Capital Turnover secara parsial memiliki tidak berpengaruh dan tidak signifikan terhadap Pertumbuhan Laba pada perusahaan sektor makanan dan minuman yang terdaftar di Bursa Efek Indonesia (BEI).

b. Debt To Total Asset secara parsial berpengaruh positif dan signifikan terhadap Pertumbuhan Laba pada perusahaan sektor makanan dan minuman yang terdaftar di Bursa Efek Indonesia (BEI).

c. Receivable Turnover secara parsial berpengaruh negatif dan signifikan terhadap Pertumbuhan Laba pada perusahaan sektor pertambangan yang terdaftar di Bursa Efek Indonesia (BEI).

d. Working Capital Turnover, Debt To Total Asset dan Receivable Turnover secara simultan memiliki pengaruh positif dan signifikan terhadap Pertumbuhan Laba pada perusahaan sektor pertambangan yang terdaftar di Bursa Efek Indonesia (BEI).

\section{DAFTAR PUSTAKA}

Angkoso, Nandi. (2009). Akuntansi Lanjutan. Yogyakarta : Yayasan Badan Penerbit Gadjah Mada.

Arfan Ikhsan \& Misri. (2012). Metodologi Penelitian. Bandung : Citapustaka Media Perintis.

Chairiyah, Hasanatul. (2017). Pengaruh Debt To Equity Ratio, Perputaran Modal Kerja Dan Current Ratio Terhadap Pertumbuhan Laba Perusahaan Industri Makanan Dan Minuman Yang Go Public Di BEI Pada Tahun 2011 - 2015. Skripsi : Universitas Negeri Medan.

Ghozali, Imam. (2013). Aplikasi Analisis Multivariate Dengan Program IBM SPSS 21 Update PLS Regresi. Semarang : Yayasan Badan Penerbit Universitas Dipoegoro.

Harahap, Sofyan Syafri. (2015). Analisis Kritis Atas Laporan Keuangan. Jakarta : Rajawali Pers.

Hery. (2017). Kajian Riset Akuntansi. Jakarta : Grasindo.

Juliandi, Azwar \& Irfan. (2013). Metodologi Penelitian Kuantitatif : Untuk Ilmu - Ilmu Bisnis. Bandung : Citapustaka Media Perintis. 
Jumingan. (2011). Analisa Laporan Keuangan. Jakarta : Bumi Aksara.

Kasmir. (2017). Analisis Laporan Keuangan. Jakarta : Rajawali Pers.

Lina Sari \& Wuryanti, L. (2017). Pengaruh Working Capital To Total Assets, Debt To Equity Ratio, Total Asset Turnover Dan Net Profit Margin Terhadap Pertumbuhan Laba Pada PT. Bukit Asam (Persero) Tbk. Periode 2009 - 2014. Jurnal Riset Akuntansi Dan Manajemen, Vol. 6,No. 1.

Munawir. (2014). Analisis Laporan Keuangan. Yogyakarta : Liberty.

Purwitasari, Rossy Enji Nandi. (2019). Pengaruh Total Asset Turnover, Return On Asset Dan Debt To Asset Ratio Terhadap Pertumbuhan Laba. Jurnal Ilmu Dan Riset Manajemen, Vol. 8, No. 3.

Riyanto, Bambang. (2008). Dasar - Dasar Pembelanjaan Perusahaan. Yogyakarta : Yayasan Badan Penerbit Gadjah Mada.

Rudianto. (2012). Pengantar Akuntansi : Konsep Dan Teknik Penyusunan Laporan Keuangan. Jakarta : Erlangga.

Sari, Linda Purnama \& Widyarti, E, T. (2015). Analisis Pengaruh Rasio Keuangan Terhadap Pertumbuhan Laba (Studi Kasus Perusahaan Food And Beverages Yang Terdaftar Di Bursa Efek Indonesia Periode 2009 Sampai Dengan 2013). Diponegoro Journal Of Management, Vol. 4, No. 4, Hal : $1-11$.

Sugiyono. (2013). Metode Penelitian Bisnis. Bandung : Alfabeta. 